\title{
Atmospheric pollen and spore content in the urban area of the city of Medellin, Colombia
}

\author{
Fernando Alzate Guarín ${ }^{1,2}$, Mario Alberto Quijano Abril ${ }^{1}$, Astrid Alvarez ${ }^{1}$ and Ramiro Fonnegra ${ }^{1}$ \\ Received: 29.08.2013; accepted: 24.06.2014
}

\begin{abstract}
Atmospheric pollen and spore content in the urban area of the city of Medellin, Colombia). The atmosphere of the urban area of the city of Medellin, Colombia was monitored with the objective of identifying airborne pollen and spores throughout a whole year. Sampling was performed between February 2010 and March 2011, coinciding with the La Niña climate phenomenon, which is characterized by a considerable increase in precipitation. Samples of airborne spores and pollen were obtained from a suction Hirst-type volumetric sampler. A total of 62 pollen and spores types were recorded during sampling, of which 30 were angiosperms, two were gymnosperms, 10 were monilophytes, and 20 were fungi. The families displaying the highest pollen counts were Oleaceae, Poaceae, Cyperaceae, Chenopodiaceae and Polypodiaceae. We recorded an inverse relationship among precipitation and the quantity and diversity of pollen grains and fern spores. The angiosperm and gymnosperm taxa showed the greatest recorded grains throughout the sampling year with respect to the species mentioned herewith, which have been reported as allergenic in various aerobiological studies.
\end{abstract}

Keywords: La Niña phenomenon, Palynology, Pollinosis, Tropics

RESUMEN- (Polen atmosférico y esporas contenidas en el área urbana de la ciudad de Medellín (Colombia)). Se realizó un monitoreo de la atmosfera del área urbana de Medellín, con el objetivo de identificar polen y esporas que se transportan por el aire a lo largo del año. El muestreo se realizó entre febrero de 2010 y marzo de 2011. Las muestras de polen y esporas aéreas se obtuvieron utilizando un captador volumétrico de succión tipo Hirst. En el trabajo se registraron 62 tipos polínicos y esporas, de las cuales 30 corresponden a angiospermas, dos a gimnospermas, 10 a pteridofitos y 20 a hongos. Las familias con mayor número de individuos por muestreo fueron: Oleaceae, Poaceae, Cyperaceae, Chenopodiaceae y Polypodiaceae. Se observó una relación inversamente proporcional entre la cantidad y diversidad de granos de polen y esporas de helechos encontrados, con respecto a la precipitación a lo largo del muestreo. Los taxones de angiospermas y gimnospermas que mayor cantidad de granos aportaron en los conteos durante el año de muestreo, corresponden a especies introducidas, con reportes de alergenicidad.

Palabras clave: Fenómeno LaNiña, Palinología, Polinosis, Trópicos

\section{Introduction}

A great number and diversity of particles are found suspended in the air, constituting the atmospheric aerosols. These particles include fungus, bryophyte and fern spores, which show diameters of 1-100 $\mu \mathrm{m}, 6-30 \mu \mathrm{m}$ and 20-60 $\mu \mathrm{m}$, respectively, as well as gymnosperm and angiosperm pollen, with diameters of 10-100 $\mu \mathrm{m}$ (Mandrioli et al. 1998). Studying these airborne particles is the main goal of aerobiology, a discipline that seeks to understand the spread of allergenic and other diseases in humans, animals and plants in order to prevent their potential harmful effects (Lacey \& West 2006). Aerobiology encompasses different fields aimed at diagnosing and solving biological and environmental problems in disciplines such as medicine, phytopathology, entomology, meteorology, environmental studies, agriculture and criminology (Dopazo et al. 2000, Brown 2004).

The main sources of atmospheric pollen are from anemophilous plants, especially grasses, gymnosperms and some angiosperms (Lacey \& West 2006). In the tropics, wind-dispersed plants are less numerous and diverse compared to temperate zones (Sakai 2001). Anemophilous pollination in angiosperms is a derived

1. Universidad de Antioquia, Instituto de Biología, Calle 67 No 53-108, Medellín, Colombia

2. Corresponding author: alzatef@gmail.com 
characteristic that has arisen, in an independent manner, 65 times during the evolutionary history of these plants and is present in $10 \%$ of the species in this plant group (Ackerman 2000). According to Friedman and Barrett (2009), the pollen of anemophilous plants is smaller, meaning that it exhibits a lower inertia, which facilitates the removal of these grains from the anthers. This type of pollen also shows a smaller size variation range $(17-58 \mu \mathrm{m})$ compared to animaltransported pollen $(5-200 \mu \mathrm{m})$.

In contrast to the notion that anemophily is a rare phenomenon in tropical wet forests, several studies and authors have demonstrated the occurrence of this pollination strategy in a large number of tree and herbaceous species (Lewis 1986. Sakai 2001). A study carried out by Hurtado and Riegles-Goihman (1986) in Caracas, Venezuela, using Durham traps recorded 68 pollen morphotypes in samples collected within a period of one year, corresponding to a total of 11,093 pollen grains and spores in an area of $1,775 \mathrm{~cm}^{2}$. Such authors concluded that the tropical flora is responsible for a small proportion of airborne pollen, with the following genera being the most important in this context: Cecropia, Cupressus, Chenopodium (included now in Dysphania), Pfaffia, Plantago and members of the Asteraceae and Polypodiaceae families. In another study, performed in La Habana, Cuba, González et al. (2009) applied a gravimetric method and found that the main airborne pollen types are produced by trees, especially members of the Oleaceae, Casuarinaceae and Asteraceae families and herbs belonging to the Poaceae family.

Fungus and fern spores also constitute an important proportion of the atmospheric aerosols. In European countries, the most important of these species include members of the genera Alternaria, Cladosporium, Didymella, Leptosphaeria, Epicoccum and Ganoderma (Oliveira et al. 2009). The study of atmospheric spores is crucial because many of these spores can act as plant pathogens or cause either respiratory or allergenic diseases in humans (Vélez et al. 2009).

Diverse types of palynological components of the atmospheric aerosols are responsible for causing public health-related problems. Respiratory diseases of allergenic origin have increased over the last 20 years, affecting the quality of life of the people who suffer from them, representing $10-25 \%$ of the worldwide population (Olabuenaga et al. 2007). The percentage of people who are allergic to pollen grains and fungal spores can reach high levels in densely populated areas such as Medellin, bolstered by the presence of toxic atmospheric contaminants in such cities. The high prevalence of allergenic pathologies reported in the city of Medellin (Dennis et al. 2004) is most likely correlated with the types of pollen and spores present in the atmosphere in this region.

Most aerobiological studies have been performed in temperate and seasonal areas (Oliveira et al. 2009), where cases of pollen allergy are more often reported, diagnosed and described. Comparatively few of these studies are performed in tropical areas, where the populations also display many cases of allergies, although their causes are unknown. Furthermore, urban vegetation is clearly likely to have an important effect on this type of allergy. However, silviculture planning in cities does not take into account these potential problems.

In Colombia, several aerobiological studies have been performed, such as those published by Sánchez and Fernández $(1965,1966)$ about allergenic pollen grains; Sánchez and Ortiz (1961), Álvarez et al. (1965), Grose et al. (1967), Rincón \& Macías (1969) and Hurtado et al. (1989) regarding allergenic fungi; whereas Schnetter (1971) conducted studies of pollen sedimentation. Between 1998 and 2000, an epidemiological study was carried out in six Colombian cities (Barranquilla, Bogotá, Bucaramanga, Cali, Cartagena and Medellín) where symptoms associated with asthma, rhinitis and atopic dermatitis were found to show prevalences of $10.4 \%, 22.6 \%$ and $3.9 \%$, respectively, in the registered population. Allergic rhinitis displayed a cumulative prevalence of $31.1 \%$, with Medellin being the most affected city among those included in the study (Dennis et al. 2004). At the same study, it was established that allergic rhinitis exhibited a cumulative prevalence of $31.3 \%$, with the group showing the greatest problems among individuals aged 12 to 18 years, and the city of Medellin again appeared to be the most affected city among those included in the study. The prevalence of asthma symptoms in the adult population may vary between $2.4 \%$ and $30.3 \%$ according to a report by the Global Initiative for Asthma (GINA), which coincides with the data obtained in Colombia.

In aerobiological studies performed Bogotá, it has been found that the two main species contributing to atmospheric pollen levels are Fraxinus chinensis, exhibiting a contribution of nearly $32 \%$, and Cecropia sp., accounting for $8 \%$ of the total pollen collected during sampling. Based upon these studies, the allergenic capacity of these two types of pollen was determined by using specific immunoglobulin $\mathrm{E}$ (Rodríguez \& Leal 2000). Species of the genus 
Cecropia are generally reported as part of atmospheric pollen in various countries, from Mexico to Brazil, as shown by Hurtado and Alson (1990), who calculated the contribution of Cecropia pollen in the atmosphere in Caracas (Venezuela) to be $29 \%$ out of the total pollen grains collected.

The present study was carried out in the city of Medellin, which is located in a landform known as the Aburra Valley. From a geological standpoint and based on the formation of the Aburra Valley, it is considered a deep depression in the center of a flatland, where winds are important in the dispersion of bio-particles (Bedoya 2002). The location of the city urban area results in a seasonal rain regime including a dry period and favoring conditions to promote pollen and spore dispersal by wind. Furthermore, the frequent and anthropic-increasing interventions from the city could contribute to the dispersion of various particles in the atmosphere.

In this study, airborne organic material from the urban area of Medellin was analyzed, aimed at identifying different types of particles in the air which have been reported in other countries as being potentially allergenic and responsible for multiple diseases. This is a pioneering study for Colombia, as it is the first to apply a quantitative approach using a suction volumetric Hirst-type sampler.

\section{Material and methods}

Location of the aerobiological station -The sampling station was mounted on the campus of the University of Antioquia $\left(6^{\circ} 16^{\prime} 2.7^{\prime \prime} \mathrm{N}\right.$ and $\left.75^{\circ} 34^{\prime} 6.2^{\prime \prime} \mathrm{W}\right)$, in the central area of the city of Medellin. Medellin is located in an Andean narrow valley of the Premontane Wet Forest lifezone (PM-wf) at an altitude of $1,480 \mathrm{~m}$, where the temperatures range between 16 and $29^{\circ} \mathrm{C}$, and the mean annual precipitation is close to $1,700 \mathrm{~mm}$, with a population of 2,7 million inhabitants. The rainy days per month are typically between 12 and 25, with considerable variations due to climatic phenomena such as El Niño and La Niña. Sampling was performed between February 2010 and March 2011, during the La Niña climate phenomenon, which is characterized by a considerable increase in precipitation. The prevailing wind direction in the city is north-westerly (Redaire 2011).

Sample collection - Airborne pollen and spores were collected by using a modified Hirst-type (model VPPS 2000) volumetric suction sampler, placed on the roof of the Engineer Faculty of the University of Antioquia, at $17 \mathrm{~m}$ above ground level (figure 1). This area is surrounded by native and exotic vegetation, represented by trees, shrubs, herbs and epiphytes. The campus is surrounded by the Medellin botanical garden and other parks with abundant vegetation (Idárraga et al. 2011). Each week, when the sampling cycle was completed, the drum was replaced. The sampling drum was prepared using Melinex tape and liquid silicone, which trapped pollen grains and spores. Samples were secured during transportation to avoid contamination with outside particles of the local sampler. Drum exchange was performed on site, ensuring that the incoming air volume was kept constant at $10 \mathrm{~L} / \mathrm{min}$.

Sample processing - The Melinex tape strips from the traps were spread out and cut into $48 \mathrm{~mm}$-long fragments, which corresponds to the length of the daily rotation period of the drum. Once the daily fragments were obtained, they were mounted on microscope slides previously impregnated with translucent glycerinated gelatin. The upper part of the tape was covered with fuchsine-enriched glycerinated gelatin and heated to $35^{\circ} \mathrm{C}$ to facilitate the fixation, staining and subsequent identification of the collected particles.

Pollen and spore counts - The identification and counting of captured particles required a detailed microscopic sampling analysis, which was performed in the palynology laboratory of the University of Antioquia. Counting was performed by with drawing representative subsamples from each plaque, in which four longitudinal sweeps were examined, separated by a fixed distance from each other and from the upper and lower edges of the tape, representing $12-13 \%$ of the sample (Galán et al. 2007). This methodology was based on that proposed by the European Aeroallergen Network (EAN). Counting and identification of pollen grains and spores were performed with a compound optical microscope with a $10 \times$ eyepiece and $40 \times$ and $100 \times$ objective lenses.

Palynological identification of pollen, fern and fungal spores was performed based on the available literature on this topic (Erdtman 1966, Smith 1984, Roubik \& Moreno 1991, Barros \& Barth 1994, Bedoya 2002, Ulloa \& Hanlin 2002, Sáenz \& Monserrat 2003). All of the plaques fixed during sampling were observed and studied in the laboratories of the Aerobiology Group of the Department of Biodiversity and Environmental Policy at the Universidad de León, Spain. To estimate the total pollen grains and spores per $\mathrm{m}^{3}$, a correction factor was calculated based on the characteristics of the sampler (volume of air intake per unit of time, size of the entrance and area), 
sampling area, number of count lines per plaque and microscope, according to Galán et al. (2007).

\section{Results}

A total of 62 pollen and spores types were recorded during sampling, of which 30 were angiosperms, two were gymnosperms, 10 were monilophytes, and 20 were fungi. The mean annual pollen and spore counts obtained throughout sampling were 569 grains $/ \mathrm{m}^{3}$ and 59 spores $/ \mathrm{m}^{3}$. Out of the 20 taxa recorded during sampling, the species Fraxinus chinensis was the greatest contributor of airborne pollen (table 1), accounting for 6,144 grains $/ \mathrm{m}^{3}$, followed by grass pollen types (472 grains $/ \mathrm{m}^{3}$ ), Cecropia peltata (297.6 grains/ $\mathrm{m}^{3}$ ), Artocarpus communis (104 grains/m³), Eugenia malaccensis (91.2 grains $\left./ \mathrm{m}^{3}\right)$, palm trees ( 73.6 grains/ $\mathrm{m}^{3}$ ) and Dysphania ambrosioides (51.2 grains $\left./ \mathrm{m}^{3}\right)$. The latter is the only species of the genus occurring in the region and E. malaccensis and C. peltata are trees planted abundantly in the metropolitan area, which helps to ensure the pollen identification assigned.

The prevalence of exotic species as the main contributors of atmospheric pollen grains was evident in the obtained samples (figure 2). The pollen type of Fraxinus chinensis (Oleaceae), which is extensively planted throughout the study area, was the most abundant component of the samples. Additionally, some other pollen types which were found during the sampling period displayed only one or two records (figure 3).

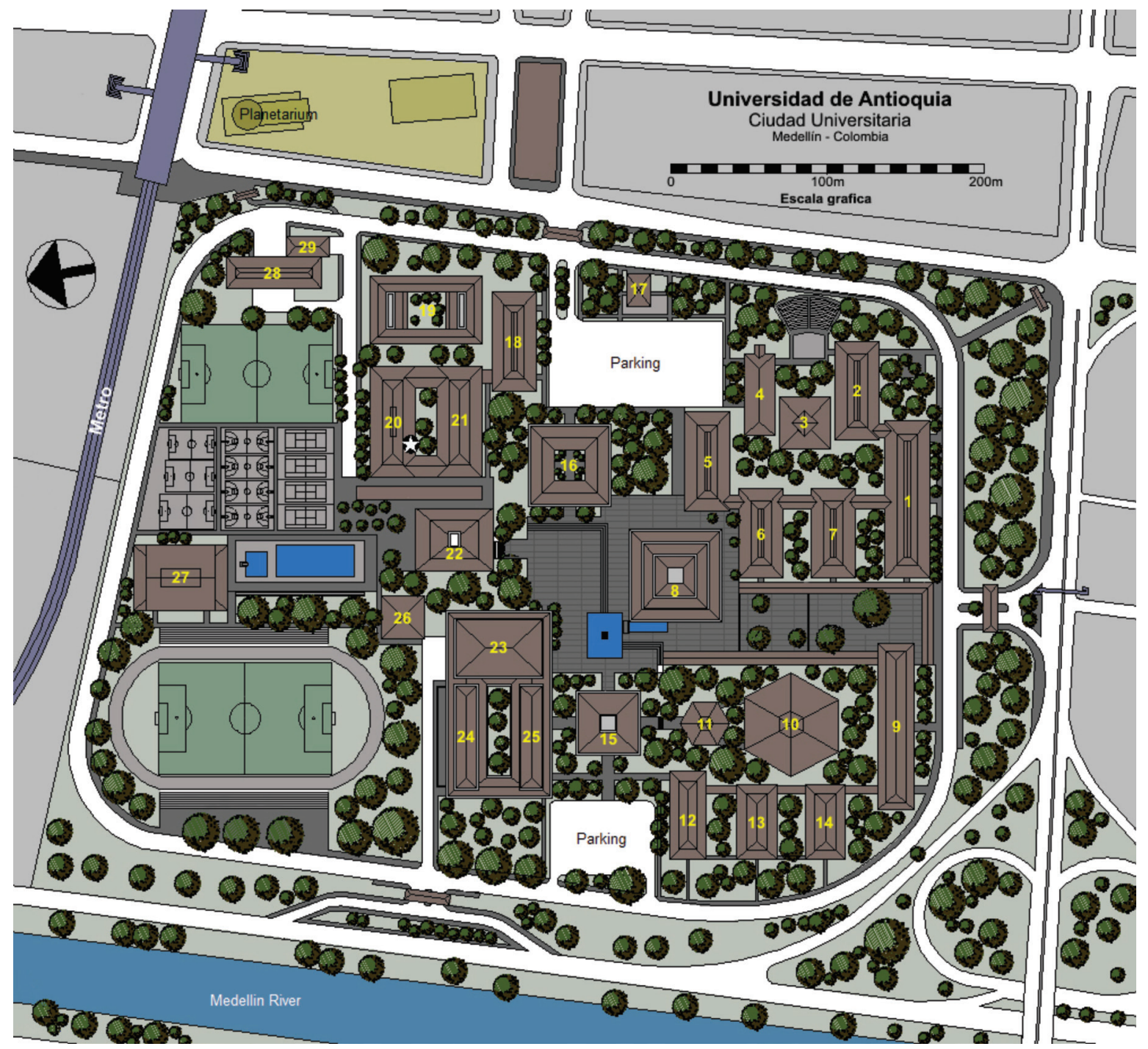

Figure 1. Sampling site at the campus of the University of Antioquia, Medellín, Colombia, and main vegetation sources around. 
Table 1. List of the main pollen and spore types monitored in the atmosphere of Medellín, Colombia, total numbers of pollen grains and spores counted, and concentration per $\mathrm{m}^{3}$.

\begin{tabular}{lcc}
\hline Pollen and spore types & Pollen grains or spores $/ \mathrm{m}^{3}$ & Total grains \\
\hline Alternanthera sp. & 3.2 & 2 \\
Artocarpus communis & 104.0 & 65 \\
Asplenium sp. & 240.0 & 150 \\
Cecropia peltata & 297.6 & 40 \\
Cladosporyum sp. & 8.0 & 5 \\
Cupressus lusitanica & 33.6 & 21 \\
Dysphania ambrosioides & 51.2 & 32 \\
Epicoccum sp. & 20.8 & 13 \\
Eugenia malaccensis & 91.2 & 57 \\
Fern 1 & 17.6 & 11 \\
Fern 2 & 169.6 & 106 \\
Fern 3 & 3.2 & 2 \\
Fraxinus chinensis & 6144.0 & 3.840 \\
Galinsoga quadriradiata & 28.8 & 18 \\
Poaceae & 472.0 & 295 \\
Melastomataceae & 1.6 & 1 \\
Arecaceae & 73.6 & 46 \\
Periconia sp. & 56.0 & 35 \\
Pinus patula & 20.8 & 13 \\
Polypodiaceae 1 & 86.4 & 54 \\
Polypodiaceae 2 & 25.6 & 16 \\
Psychotria sp. & 46.4 & 29 \\
Puccinia sp. & 137.6 & 86 \\
Rumex sp. & 3.2 & 2 \\
Tranzschelia anemones & 1.6 & \\
\hline & & \\
& & \\
\hline
\end{tabular}

\section{Percentage}

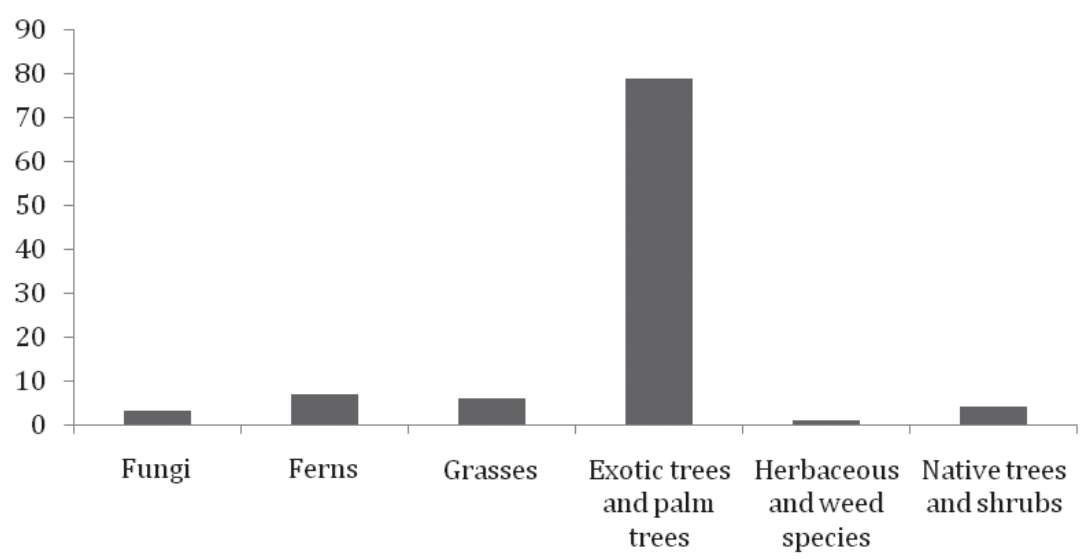

Figure 2. Percentage of pollen grains and spores for each of the plant categories defined in this study, University of Antioquia, Medellín, Colombia. 
This study provides a classification of the main taxa contributing spores and pollen to the atmosphere of the city of Medellin, according to habitat and origin of the taxa.

Grasses (Poaceae) - This category includes hundreds of species, with the majority of these genera being responsible for pollinosis (e.g., Phleum, Dactylis, Lolium, Cynodon, Trisetum) and leading cause of allergies in previous studies from various countries (Rodríguez \& Leal 2000, Mösges \& Klimek 2006, Grinn \& Mika 2008, González et al. 2009). In the study area, grass species are very abundant and display different uses as ornamental plants and fodder.

Exotic trees and palm trees - The pollen types of this group which were most commonly found in the study area are Archontophoenix cunninghamiana, Cupressus lusitanica, Dypsis lutescens, Eugenia malaccensis, Fraxinus chinensis, Mangifera indica, Pinus patula, Roystonea regia, Spathodea campanulata, Tibouchina lepidota and Tibouchina urvilleana. This group of species accounted for the greatest amount of pollen in the atmosphere (figure 2), with the largest amount contributed by Fraxinus chinensis being especially noteworthy. Fraxinus chinensis pollen has been found to be an important cause of allergies in the exposed population in various studies addressing pollinosis.

Native trees and shrubs - The native species of the forests that are close to the study area belong to this group, and they were represented in the samples by pollen types belonging to the genera Cecropia and Psychotria.

Herbaceous and weed species - This group includes the greatest number of pollen types identified in the samples, many of which are used in gardening, while some are invasive species. The most relevant pollen types in this category were Alternanthera sessilis, Dysphania ambrosioides, Galinsoga quadriradiata and Rumex crispus.

Ferns - Three spore types of ferns were identified in this study, which belong to the families Gleicheniaceae
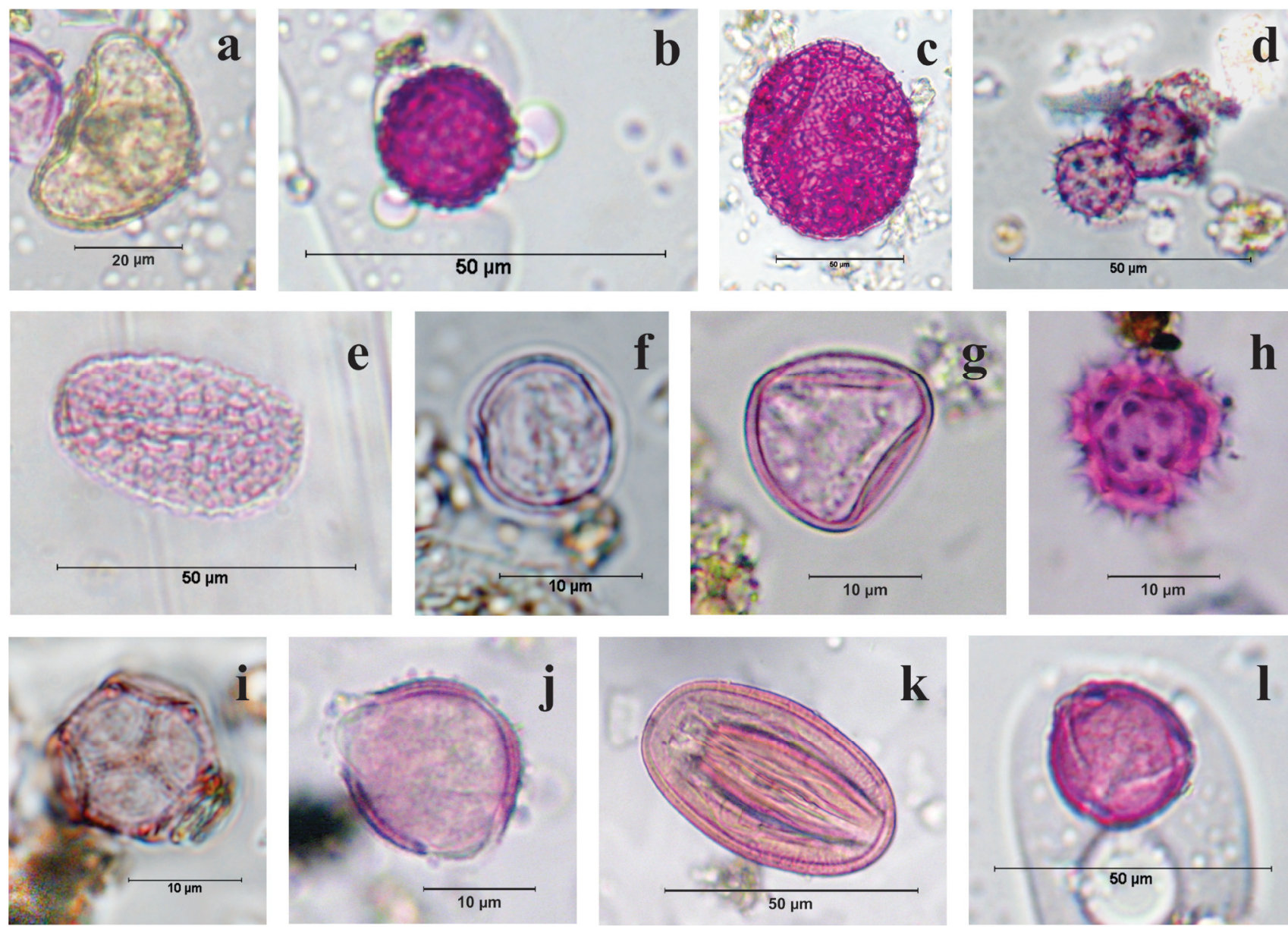

Figure 3. Pollen and spores types recorded only once or twice during sampling, University of Antioquia, Medellín, Colombia. a. Adiantum sp. b. Ambrosia sp. c. Bombacoideae. d. Asteraceae. e. Tillandsia sp. f. Pilea sp. g. Arecaceae. h. Galinsoga quadriradiata. i. Alternanthera sessilis. j. Psychotria. k. Tibouchina. 1. Ricinus. 
and Polypodiaceae. The most commonly found ferns in the area are species that were introduced as ornamentals and a group of native species, which exhibit an epiphytic life form.

Fungi - In addition to the registered palynomorph types, 20 fungal spore types were reported, which belong to nine families. The atmospheric fungal spore load in Colombia has only been described previously by Cabrales et al. (2004). The sampling and analysis performed in this study did not include counting, but only the occurrence of fungal spores in the city's atmosphere was recorded. Most of the identified taxa correspond to the genera that are most commonly reported as allergenic in other latitudes (Grinn \& Mika 2008, Oliveira et al. 2009). The presence and concentration of fungal spores in the atmosphere has been correlated with the relative humidity in the study area (Troutt \& Levetin 2001, Morales 2003, Sáenz \& Monserrat 2003), which is a condition that favors the constant reproduction of these organisms (Oliveira et al. 2009). This condition was an important factor in the present study because, due to the La Niña climate phenomenon, Medellin showed the highest historically recorded values of relative humidity during the study period. Some fungal genera associated with allergenic processes were found in the atmosphere of Medellin, such as Agrocybe, Alternaria, Arthrinium, Beltrania, Cladosporium, Curvularia, Dreschslera, Epicoccum, Fusarium, Leptosphaeria, Nigrospora, Pithomyces, Pleospora, Puccinia, Tetraploa, Torula and Ustilago (figure 4).

\section{Discussion}

A total of 62 pollen and spore types were recorded in the samples, of which 30 corresponded to angiosperms, two to gymnosperms, 10 to monilophytes (ferns) and 20 to fungi. The quantity and diversity of pollen types and spores were most likely influenced by the atypical climate phenomena that were prevaling during the sampling period, which might have influenced their dispersal in the air.
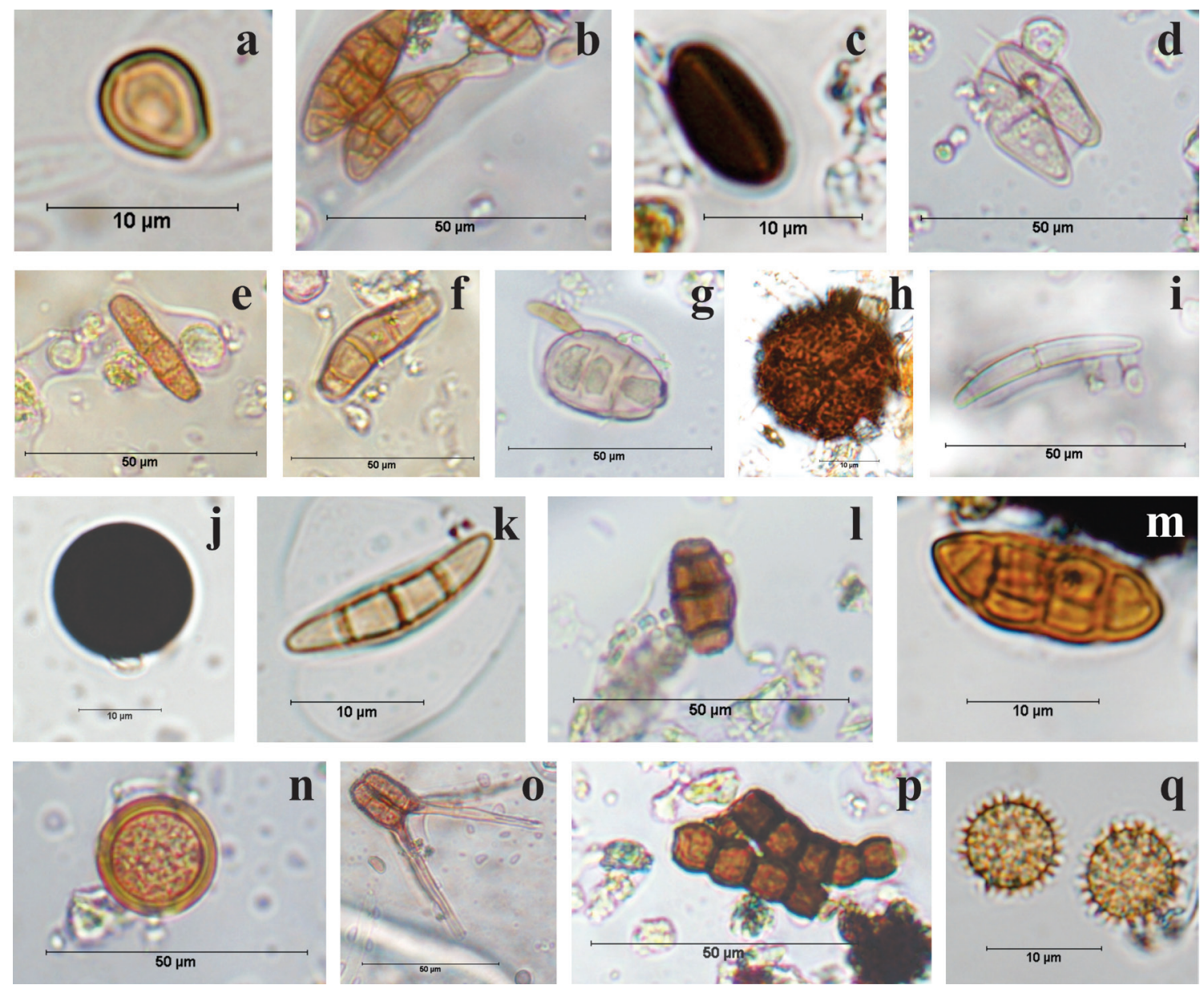

Figure 4. Fungal spore types found during sampling, University of Antioquia, Medellín, Colombia. a. Agrocybe sp. b. Alternaria sp. c. Arthrinium sp. d. Beltrania sp. e. Cladosporium sp. f. Curvularia sp. g. Dreschslera sp. h. Epicoccum sp. i. Fusarium sp. j. Nigrospora sp. k. Leptosphaeria. 1. Pithomyces sp. m. Pleospora sp. n. Puccinia sp. o. Tetraploa sp. p. Torula sp. q. Ustilago sp. 
According to official data, there are currently 279,769 trees that have been planted in the city of Medellin, distributed in public areas throughout the city. Out of these trees, $70 \%$ are exotic species, which were planted over the last several decades. There are historic trends in the city of Medellin regarding urban vegetation planting programs. When urban reforestation programs were established for the city in the early 1900s, the most commonly used species were native. Then, around the 1960 s, a shift towards planting became evident, introducing species belonging to the genera Eucalyptus, Pinus and Cupressus. Finally, starting in 1970, the species that were most frequently planted were exotic specimens belonging to the genera Fraxinus, Mangifera, Spathodea and Leucaena.

Throughout the first three months of sampling (February to April), the monthly precipitation records were below the historic mean due to the El Niño climate phenomenon. Then, at the beginning of the fourth month of sampling (May), the monthly precipitation records increased due to the first winter season of the year in Colombia. This first rainy season was greatly extended due to La Niña event. Increases in pollen levels in the atmosphere are generally associated with an increase or decrease in temperature and precipitation, an increase in the abundance of species with wind-dispersed pollen, abrupt changes in temperature, short and simultaneous flowering periods and the occurrence of powerful storms (González et al. 2009). During the sampling period, atypical climatic events occurred, which caused different climate trends from those historically recorded for the city of Medellin (Redaire 2011), which certainly influenced the relative amount of pollen and spores found in the atmosphere (figure 5).

Aerobiological sampling was performed almost completely under conditions of high precipitation, according to monthly rain records, which surpassed historic levels due to the La Niña phenomenon. This situation favored the occurrence of natural disasters in Colombia, such as flooding and landslides, which influenced the phenological cycles of plants. As a matter of fact, September of 2010 was the second rainiest September on record for the city of Medellin over the last 45 years with a precipitation of $266.5 \mathrm{~mm}$, compared to historical averages of precipitation of $151.9 \mathrm{~mm}$ for the month of September (SIATA 2010). These climate phenomena occurred in parallel with the amounts of pollen and spores observed in this study, and as it is evident in figure 4, the amount of pollen recorded decreased markedly during the rainiest months, although this is not evident for grasses and Cecropia peltata pollen types, which remained high atmospheric pollen levels in this rainy period. Various studies have shown how precipitation results in atmospheric washing, cause the pollen load to precipitate as well as flower falling, meaning that pollen is not recorded in aerobiological sampling (Pérez et al. 2009).

The weather in this region is characterized as dry at the beginning and middle of the year. However, during sampling, a La Niña climate event occurred, caused by an increase in trade winds in the Intertropical Convergence Zone and early movement of this zone towards the north with respect to its normal location. This event was related to an increase in precipitation throughout the sampling period, which became evident at the beginning of the second quarter and lasted until its end (figure 5).

Very few aerobiological studies have been carried out in Colombia, and those that exist have employed methodology which was not very efficient such as Durham method, non-used for long-term sampling. Sánchez and Fernández (1966) performed an aeropalynological sampling on the savannah in Bogotá and reported the occurrence of atmospheric pollen produced by some typical species from the city. The results of such studies and those presented herewith indicate that nearly $70 \%$ of airborne pollen corresponds to exotic species. Another study conducted in Colombia by Cabrales et al. (2004) involved aerobiological sampling of the atmosphere of the city of Bucaramanga, which is one of the most populated cities in the country. Such authors reported that $85 \%$ of the collected bioparticles belonged to fungi and $13 \%$ to pollen grains, with a high abundance of exotic tree species being identified.

The present study was the first to be developed in Colombia using a suction volumetric Hirst-type sampler. Nevertheless, our findings coincide with those obtained in similar studies carried out in Neotropical areas, such as those reported by Hurtado and Riegles-Goihman (1984) from Venezuela, where 68 pollen and spores types were found by using the Durham method. These authors emphasized the presence of atmospheric pollen grains belonging to the families Myrtaceae, Chenopodiaceae and Asteraceae as well as spores of ferns which belong to the family Polypodiaceae. The taxa reported for Venezuela were also present in the atmosphere of Medellin (figure 6) and were the most commonly recorded throughout sampling.

The genera of fungi that were most commonly found during sampling were Alternaria and Puccinia, 
which is consistent with the results of aerobiological studies performed in Europe (Olabuenaga et al. 2007). A low load of allergenic pollen in the atmosphere was observed, and an inversely proportional relationship was found between precipitation and the number and diversity of fern spores and pollen grains. It was also noted that the angiosperm and gymnosperm taxa which contributed the largest amounts of pollen corresponded to introduced species, many of which have been reported to be allergenic in various studies (Lacey \& West 2006).

In most tropical countries, the diagnosis and treatment of certain allergenic diseases are based on medical trials conducted with pollen and spores of temperate origin. This situation can be attributed to the lack of information on airborne particles from tropical countries, showing that further studies are required to enhance reliable knowledge and information since it is a matter of public health which remains poorly studied and understood in tropical areas. Therefore, studies addressing this topic are very important for defining and quantifying the effect of the airborne pollen load on the health of people who live in cities located at these latitudes, especially when considering the size of the population that inhabits the tropics.

The selection and incorporation of plant species for urban reforestation include some criteria related to growth, rusticity and ornamental qualities, among others. However, in tropical countries, these criteria do not include possible effects on public health due to pollinosis.
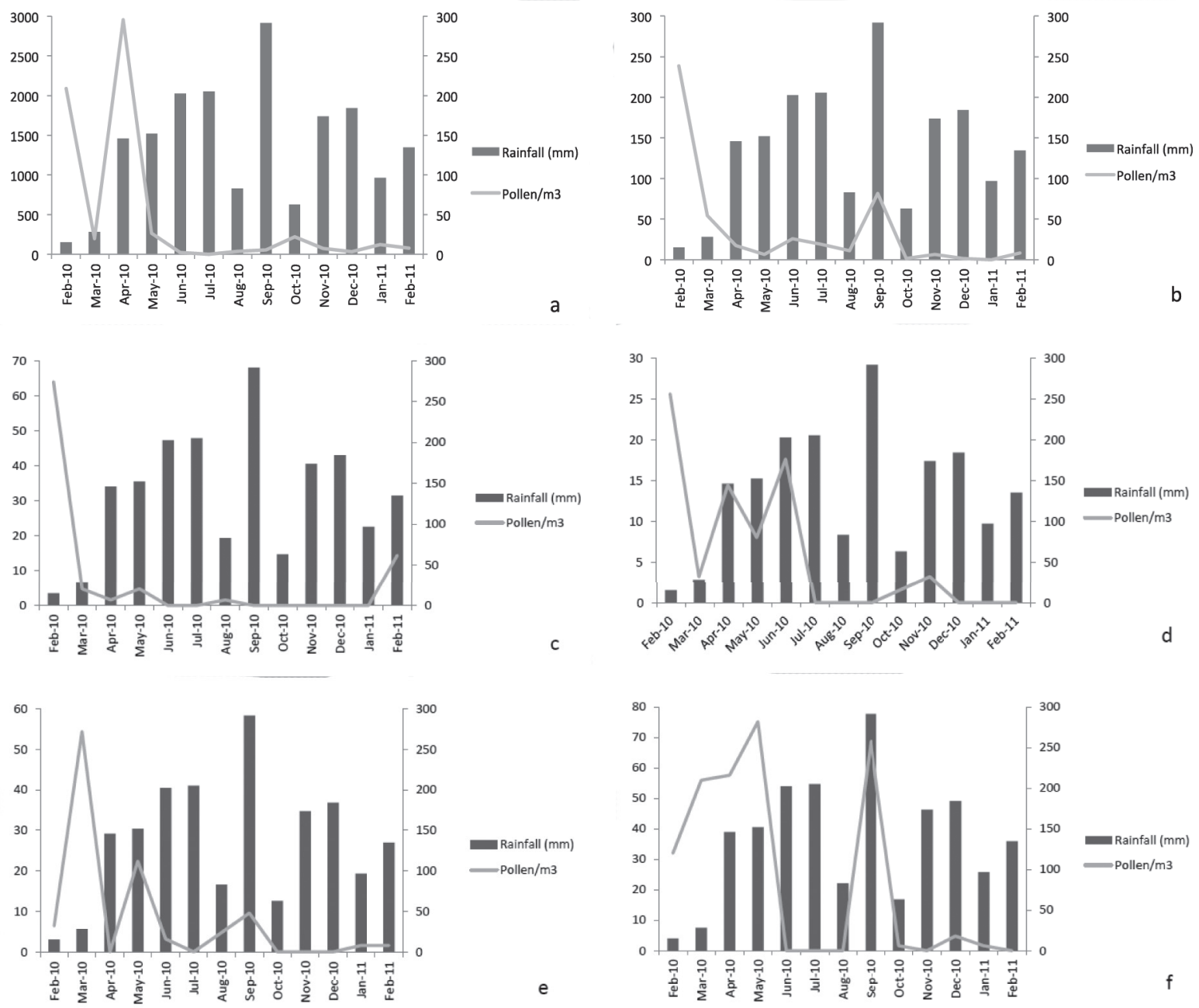

Figure 5. Relationship between the amount of pollen $/ \mathrm{m}^{3}$ and precipitation values for the sampling period, University of Antioquia, Medellín, Colombia. a. Fraxinus chinensis. b.Grasses. c. Eugenia malaccensis. d. Arecaceae. e. Artocarpus communis. f. Cecropia peltata. 

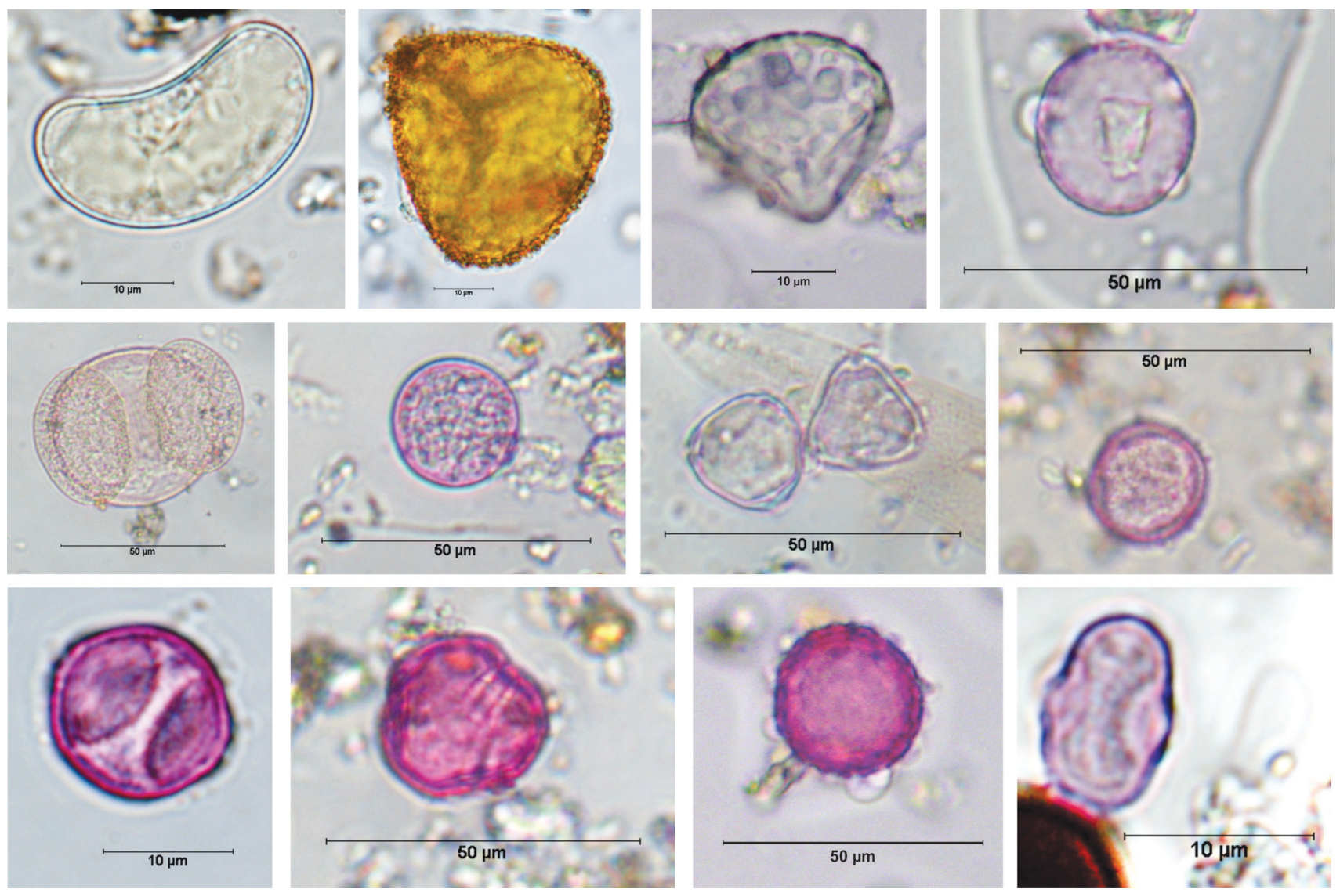

Figure 6. Pollen grains and spores of the most common types in the samples, University of Antioquia, Medellín, Colombia. a. Gleicheniaceae. b. Polypodiaceae. c. Polypodiaceae. d. Cupressus lusitanica. e. Pinus patula. f. Grass. g. Eugenia malaccensis. h. Fraxinus chinensis. i. Artocarpus communis. j. Rumex crispus. k. Dysphania ambrosioides. 1. Cecropia peltata.

Species such as Fraxinus chinensis and Cecropia peltata, which are abundantly planted in the city of Medellin, shall be excluded from urban reforestation programs taking into account that they induce respiratory diseases. From a public health standpoint, it is crucial to define more stringent criteria for the selection of species to be planted in tropical cities, where the occurrence of pollinosis is not well documented.

\section{Acknowledgments}

This study was possible thanks to funding provided by Universidad de Antioquia, Colombia. The authors also wish to thank for the support, counseling and facilities offered by Drs. Rosa Valencia and Delia Fernández from the Aerobiology Group of Universidad de León, Spain.

\section{Literature cited}

Ackerman, J. 2000. Abiotic pollen and pollination: ecological, functional, and evolutionary perspectives. Plant Systematics and Evolution 222: 167-185.
Álvarez, R., Reyes, M. \& Madriñan C. 1965. Encuesta sobre hongos ambientales en la ciudad de Cali. Antioquia Médica 15: 497-502.

Barros, M. \& Barth, O. 1994. Catálogo sistemático do pólen das plantas arbóreas do Brasilmeridional. XXVIII - Burseraceae e Clethraceae. Revista Brasileira de Biologia 54: 317-322.

Bedoya, G. 2002. Granos de pólen potencialmente alergénicos en el valle de Aburrá.Tesis de grado en biología, Universidad de Antioquia, Medellín.

Brown, A. 2004. The combine use of pollen and mineralogy in war crimes investigations in NE Bosnia on behalf of the United Nations International Criminal Tribune for the former Yugoslavia. Polen 14: 116-117.

Cabrales, C., García, H. \& Ramírez, G. 2004. Estudio aerobiológico en la ciudad de Bucaramanga. Revista de alergia, Asma e Inmunología. Available in http://www. encolombia.com (access in 22-IX-2012).

Dennis, R., Caraballo, L., García, E., Caballero, A., Aristizábal, G., Córdoba, H., Rodríguez, N., Rojas, M., Blanco, A., Egea, E., Orduz, C.\& Cardona, R. 2004. Asthma and other allergic conditions in Colombia: a study in 6 cities. Annals of Allergy, Asthma and Immunology 4: 93-96. 
Dopazo A., Mendez, J. \& Maira, M. 2000. Aerobiología en Galícia: estación de Viveiro. REA 6: 111-114.

Erdtman, G. 1966. Pollen morphology and plant taxonomy (An introduction to Palinology I, Angiosperms). Hafner Publishing Company, Stockholm.

Friedman, J. \& Barrett S. 2009. Wind of change: new insights on the ecology and evolution of pollination and mating in wind-pollinated plants. Annals of Botany103: 1515-1527.

Galán, C., González, P., Alcázar, P.\& Domínguez, E. 2007. Manual de Calidad y Gestión de la Red Española de Aerobiología. Servicio de publicaciones Universidad de Córdoba.

González, O., Fuentes, Y., Rodríguez, R., Martínez, I., Rodríguez, P.\& Pérez, V. 2009. Calendario polínico en uma región de Ciudad de La Habana. VacciMonitor 18: 1-4.

Grinn, A. \& Mika, A. 2008. Selected airborne allergenic fungal spores and meteorological factors in Szczecin, Poland, 2004-2006. Aerobiologia 24: 89-97.

Grose, E., Szexeny, M. \& Muñoz, N. 1967. Airbone fungus spores in Bogotá, Colombia: a five year study. Sabouraudia 6: 42-50.

Hurtado, I. \& Alson, J. 1990. Air pollen dispersal in a tropical area. Aerobiologia 6:122-127.

Hurtado, I.\& Riegles-Goihman, M. 1984. Air sampling studies in tropical America (Venezuela). Frequency and periodicity of pollen and spores. Allergologia et Immunopathologia 12: 449-454.

Hurtado, I. \& Riegles-Goihman, M. 1986. Air-Sampling Studies in a Tropical Area. Grana 25: 63-68.

Hurtado, I., Leal, F., Rodríguez, C., García, G. \& AlsonHaran, J. 1989. A one year survey of airbone pollen and spores in the neotropical city of Bogotá (Colombia). Allergologia et Immunopathologia 17: 95-104.

Idárraga, A., Ortiz, R., Callejas, R. \&Merello M. 2011. Flora de Antioquia: catálogo de las plantas vasculares. Vol. II. Listado de lãs plantas vasculares del departamento de Antioquia. Programa Expedición Antioquia-2103. Universidad de Antioquia, Missouri Botanical Garden, Editorial D'Vinni, Bogotá, Colombia.

Lacey, M. \& West, J. 2006. The Air Spora: A manual for catching and identifying airborne biological particles. Springer, Netherlands.

Lewis, W. 1986. Airborne pollen of the Neotropics. Potential roles in pollination and polinosis. Grana 25: 75-83.

Mandrioli, P., Comtois, P. \& Levizzani, V. 1998. Methods in Aerobiology. Pitagora Editrice, Bologna.

Morales, J. 2003. Estudio aerobiológico de las esporas de hongos en la atmosfera de Sevilla y surelación con las variables climáticas. Tesis de Doutorado, Departamento de biología vegetal y ecología, Universidad de Sevilla, Sevilla.

Mösges, R. \& Klimek, L. 2006. Today's Allergies. Are There New Factors that Play a Role? Allergy \& Clinical Immunology International - Journal of the World Allergy Organization 18: 254-255.
Olabuenaga, S., Bianchi, M.,Vacchino, M., ColinoOzores, C. \& Fainstein, B. 2007. Polen y polinosis en San Carlos de Bariloche. Saberes 4: 42-47.

Oliveira, M., Ribeiro, J., Delgado, L. \& Abreu, I. 2009. The effects of meteorological factors on airborne fungal spore concentration in two areas differing in urbanization level. International Journal of Biometeorology 53: 61-73.

Pérez,C., Gassmann, M. \& Covi, M. 2009. An evaluation of the airborne pollen-precipitation relationship with the superposed epoch method. Aerobiologia 25: 313-320.

Redaire. 2011. Red de vigilancia y calidad del aire. Available in http://www.unalmed.edu.co/redaire (access in 21-V-2011).

Rincón, M.\&Macías, M. 1969. Estudio de hongosambientales en la ciudad de Bucaramanga. Revista Universidad Industrial de Santander 6: 37-42.

Rodríguez, A.\& Leal, F. 2000. Proteínas alergénicas de Fraxinus chinensisy Cecropia sp. y reactividad cruzada entre oleáceas. Revista Asociación Colombiana de Alergias e Inmunología 9: 33-42.

Roubik, D. \& Moreno, J. 1991. Pollen and spores of Barro Colorado Island. Monographs in Systematic Botany 36: 1-268.

Sáenz, C. \& Monserrat, B. 2003. Esporas atmosféricas en la comunidad de Madrid. Documentos técnicos de saludpública. Madrid: Comunidad de Madrid consejería de sanidad.

Sakai, S. 2001. Thrips pollination of androdioecious Castilla elastica (Moraceae) in a Seasonal Tropical Forest.American Journal of Botany 88: 1527-1534.

Sánchez, M. \& Fernández, A. 1965. Allergenic pollens in Bogotá, Colombia, South America. Journal of Allergy 38: 48-50.

Sánchez, M. \& Fernández, A. 1966. Allergenic pollens in Bogotá, Colombia, South America. Journal of Allergy 38: 46-50.

Sánchez, M. \& Ortiz, L. 1961. Hongos alergógenos en la ciudad de Bogotá. Revista Iberoamericana de Alergología 9: 31-35.

Schenetter, R. 1971. Estudio de sedimentación actual de polen en Santa Marta, Colombia, Suramérica. Caldasia 11:91-98.

SIATA. 2010. Sistema de AlertaTemprana. Available in http://www.siata.gov.co (access in 10-XII-2010).

Smith, E. 1984. Sampling and identifying allergenic pollen and molds. Blewstone Press, San Antonio.

Troutt, C. \& Levetin, E. 2001. Correlation of spring spore concentrations and meteorological conditions in Tulsa, Oklahoma. International Journal of Biometeorology 45: 64-74.

Ulloa, M. \& Hanlin, R. 2002.Ilustrated dictionary of Mycology. Second edition. American Phytopathological Society. APS Press, Minnesota.

Vélez, A., Mejía, M., Salcedo, Y. \& Camargo, Y. 2009. EmisionesAtmosféricas de Origen Biológico: Generalidades, impactos asociados y medidas de control de aerosoles Fungi. Revista Facultad de Ingenierías Universidad del Magdalena 2: 19-32. 